\title{
IDIOPATHIC LIPAEMIA RETINALIS*
}

\author{
BY \\ J. F. CULLEN AND W. D. H. CONACHER \\ Department of Ophthalmology, University of Edinburgh, and Bangour General Hospital, West Lothian
}

LIPAEMIA is described by Duke-Elder (1940) as a condition wherein fat in an emulsified form is present in the blood to a degree which alters its appearance. On the evidence available at the time of writing he added that, with one exception - the case of Wagener (1922) - diabetes was the only reported disease wherein the condition became sufficiently marked to be seen ophthalmoscopically in the retinal vessels as lipaemia retinalis. Groom and Rucker (1950) confirmed that the appearance of the retinal vessels in this condition depended on the presence in the blood of excess neutral fat or triglycerides, i.e. fatty acids combined with glycerol. Parker and Culler (1930), in reviewing the first 38 cases of lipaemia retinalis reported in the literature, concluded that, when the fat content of the blood rose to about $3.5 \mathrm{~g} . / 100 \mathrm{ml}$. (3.5 per cent.), lipaemia retinalis appeared, and that it disappeared when the concentration fell to about $2.5 \mathrm{~g}$. $/ 100 \mathrm{ml}$. Although there is considerable variation in the figures given by various authors before and since this report-largely because of the different methods used in estimating the blood lipid levels-these figures can still be taken as approximately correct.

The clinical picture as seen in the retina is characteristic. The first changes occur in the peripheral vessels where they take on a milky appearance, and the arteries and veins become indistinguishable and are flat and ribbon-like. The appearance spreads centrally as the blood lipid content rises, and when it reaches 10 per cent. the larger vessels are involved and the vessels on the optic disc become salmon-pink in colour. Clearing of the retina occurs in the reverse direction as the blood lipid level falls. If the choroidal circulation is also involved, the fundus takes on an ivory hue. Histologically, the vessels and the perivascular lymph spaces contain a plasma loaded with fat in an emulsified state. No disturbance of retinal function is associated with these changes, nor is there any microscopic evidence that the lipaemia damages the retina in any way.

Lipaemia retinalis is seen most frequently in association with diabetes mellitus in patients with acidosis and ketosis. In the pre-insulin era such cases were commoner than today, yet only twenty cases of lipaemia retinalis were reported up to 1922 . This is probably partly because the ocular fundi are not always examined in comatose diabetic patients, when other measures are urgently called for, and by the time this is done the ketoacidosis will have been reversed and the retinal lipaemia will have disappeared. Laws and Harpur (1958) † collected 69 cases of diabetic lipaemia retinalis from the literature. They reported the youngest patient to date with the condition,

* Received for publication March 31, 1964.

tThe references to these 69 diabetic cases are available in Laws and Harpur's paper. 
a 28-month-old diabetic boy in coma, and since then two further instances have been recorded in diabetics by Godde-Jolly and Bonnin (1961) and by Appelmans, Michiels, de Vloo, Jamotton, and Massa (1961), giving a total of 72 in all.

Wagener (1922) reported the first case of lipaemia retinalis in a non-diabetic patient, a 9-year-old boy with lymphatic leukaemia who had been treated by radium. Thirteen other instances of the condition in non-diabetics have since been recorded. These will be discussed later and an attempt will be made to place them in the different categories of lipid disorder with which they were associated.

The patient whose history is detailed below is, therefore, the fifteenth recorded case of non-diabetic lipaemia retinalis, and in this man a very thorough medical and biochemical investigation failed to reveal any cause for the hyperlipaemia.

\section{Case Report}

A 40-year-old miner was admitted to Bangour General Hospital, West Lothian, under the care of one of us (W.D.H.C.) as an emergency on June 16, 1961. 36 hours previously he had developed severe left-sided abdominal pain and had vomited on two occasions. Because of a previous history of duodenal ulceration, the possibility of perforation arose and he was taken in for observation. He was not unduly distressed, his temperature was $99.8^{\circ} \mathrm{F}$., there was tenderness in the left lumbar region and left loin, and on peritoneal rebound. There was no enlargement of the liver or spleen and no skin or tendon xanthomata.

The previous history was not significant, except that in 1958, after 10 months' dyspepsia and intermittent epigastric pain, a duodenal ulcer was diagnosed following a barium meal examination. The family history was negative for diabetes or other metabolic disorder. The patient has two brothers and two sisters in good health, and thirteen healthy children.

Laboratory Investigations.-Erythrocyte sedimentation rate (Westergren) $17 \mathrm{~mm}$. and $33 \mathrm{~mm}$. in one hour on two different occasions; blood sugar $84 \mathrm{mg}$. per cent.; haemoglobin $17 \cdot 1 \mathrm{~g} . / 100 \mathrm{ml}$. (117 per cent.) - this did not correspond to the packed cell volume which was 41 per cent. Further examination of the blood then revealed that this discrepancy was due to a high lipid content of the plasma. Lipid studies were, therefore, performed by Dr. M. F. Oliver, the Royal Infirmary, Edinburgh:

$\begin{array}{lcl}\text { Serum cholesterol } & 339 \mathrm{mg} . \text { per cent. } & \text { (Normal 150-240) } \\ \text { Serum triglycerides } & 50 \mathrm{mM} . / 1 . & \text { (Normal 0.7-1.50) } \\ \text { Unesterified fatty acids } & 2,380 \mathrm{mEq} . / 1 . & \text { (Normal 500-600) }\end{array}$

These figures represented a very significant increase in triglycerides or neutral fat and in fatty acids, and on this basis a diagnosis of hyperlipaemia was made. Another barium meal examination showed some deformity of the duodenal cap, but no active ulcer. In view of the loin tenderness noted at the time of the patient's admission to hospital, a kidney lesion had to be excluded, but renal function tests were normal, as were both intravenous and retrograde pyelograms.

Progress.-The patient's general condition improved spontaneously while in hospital and he was discharged on a low-fat diet and instructed to report for follow-up. He was not seen again, however, until August, 1963, when he returned after a recurrence of the abdominal pain and was readmitted for further investigation. He had not adhered to the low-fat diet, but he had been well until the pain recurred about 2 weeks previously.

Examination.-He now weighed $61 \mathrm{~kg}$. and appeared to be in good physical condition. There was no enlargement of the liver or spleen, nor was there any evidence of cutaneous xanthomatosis or other skin disorder. There was no steatorrhoea. Blood sugar estimation was normal and there was no glycosuria. A glucose tolerance test gave a normal curve-the highest blood sugar level recorded being $139 \mathrm{mg}$. per cent. The blood presented a characteristic appearance and looked like cream.

The eyes showed typical lipaemia retinalis. 
The visual acuity was $6 / 6$ and N5 in both eyes with correction. Externally the eyes were normal, as were the pupil reactions. The media were clear and the visual fields full, and there were no subjective ocular symptoms.

Further blood lipid studies were carried out on three occasions by Dr. M. F. Oliver:

$\begin{array}{llr}\text { 19.9.63: } & \begin{array}{l}\text { Serum cholesterol } \\ \text { Serum triglycerides }\end{array} & 346 \mathrm{mg} . \text { per cent. } \\ & 20 \mathrm{mM} . / \mathrm{l} . \\ \text { 23.9.63: } & \begin{array}{l}\text { Serum cholesterol } \\ \text { Serum triglycerides }\end{array} & 512 \mathrm{mg} \text {. per cent. } \\ & 21 \mathrm{mM} . / 1 . \\ \text { 9.10.63: } & \text { Serum cholesterol } & 648 \mathrm{mg} . \text { per cent. } \\ & \begin{array}{l}\text { Serum triglycerides } \\ \text { Unesterified fatty acids }\end{array} & >50 \mathrm{mM} . / 1 .\end{array}$

The striking feature, of course, is the very marked rise in the triglycerides level, which is about fifteen times the normal. It should be mentioned, however, that the blood lipid levels in patients with hyperlipaemia fluctuate considerably from time to time and even from day to day, so that repeated examinations are called for. The figures obtained at all examinations in our patient, both before and after treatment, are set out in Table I along with the normal levels.

TABLE I

SUMMARY OF BLOOD LIPID INVESTIGATIONS

\begin{tabular}{|c|c|c|c|c|}
\hline \multicolumn{2}{|c|}{ Serum Lipids } & $\begin{array}{l}\text { Cholesterol } \\
\text { (mg. per cent.) }\end{array}$ & $\begin{array}{l}\text { Triglycerides } \\
\text { (mM./l.) }\end{array}$ & $\begin{array}{l}\text { Unesterified Fatty Acids } \\
\text { (mEq./1.) }\end{array}$ \\
\hline \multicolumn{2}{|c|}{ Normal Level } & $150-240$ & $0 \cdot 7-1 \cdot 50$ & $500-600$ \\
\hline \multirow{3}{*}{$\begin{array}{l}\text { Date } \\
\text { of } \\
\text { Reading }\end{array}$} & 10.7.1961 & 339 & 50 & 2,380 \\
\hline & $\begin{array}{c}19.9 .1963 \\
23.9 .1963 \\
9.10 .1963 \\
* \\
20.11 .1963\end{array}$ & $\begin{array}{c}346 \\
512 \\
648 \\
* \\
653\end{array}$ & $\begin{array}{r}20 \\
21 \\
>50 \\
\quad * \\
>50\end{array}$ & $\begin{array}{c}\overline{-} \\
1,620 \\
*\end{array}$ \\
\hline & $\begin{array}{r}6.2 .1964 \\
16.3 .1964\end{array}$ & $\begin{array}{l}380 \\
350\end{array}$ & $\begin{array}{r}30 \\
>50\end{array}$ & $\begin{array}{l}876 \\
805\end{array}$ \\
\hline
\end{tabular}

*Course of Atromid-S 2 g./day

Plain $x$ rays of the gall bladder and a cholecystogram were normal. Exocrine pancreatic function tests were normal as regards both enzyme and volume output. The stools contained 14 per cent. fat, of which 98 per cent. was split fat (a normal finding).

Diagnosis.-In view of these negative findings apart from the hyperlipaemia and lipaemia retinalis, a diagnosis of idiopathic hyperlipaemia was made.

Treatment.-Because the patient failed to adhere to the low-fat diet on a previous occasion, treatment was begun on October 10, 1963, with ethyl- $\alpha$-(p-chlorophenoxy)isobutyrate (C.P.I.B.) or "Atromid-S", 2 g. (eight capsules) daily in divided doses.

Result. -6 weeks later, on November 20,1963, the lipaemia retinalis had disappeared and the following levels of blood lipids were found:

$$
\begin{array}{lr}
\text { Serum cholesterol } & 653 \mathrm{mg} . \text { per cent. } \\
\text { Serum triglycerides } & >50 \mathrm{mM} . / 1 .
\end{array}
$$


Follow-up.-On February 6, 1964, the fundus picture was normal and the blood lipids were considerably lower:

$$
\begin{array}{lr}
\text { Serum cholesterol } & 380 \mathrm{mg} . \text { per cent. } \\
\text { Serum triglycerides } & 30 \mathrm{mM} . / \mathrm{l} . \\
\text { Unesterified fatty acids } & 876 \mathrm{mEq} . / \mathrm{l} .
\end{array}
$$

Members of the patient's family were also examined and blood samples from the eleven eldest of his thirteen children were analysed. None exhibited lipaemia retinalis, nor was there any gross elevation of serum lipid levels, but three had a creamy serum and will require further investigation.

\section{Discussion}

A study of the fourteen cases of this condition so far reported in the literature(Table II) shows that the underlying hyperlipaemia had arisen from a variety of causes, and that lipaemia retinalis can therefore occur as a manifestation of a variety of conditions other than diabetes mellitus. Dunphy (1950), following Thannhauser (1958), reserved the term hyperlipaemia for those cases in which neutral fat is greatly increased and in which the serum becomes milky, whereas hypercholesterolaemia, without an increase in neutral fat, does not produce a cloudly serum. Following a fatty meal

\begin{tabular}{|c|c|c|c|c|c|c|c|}
\hline $\begin{array}{l}\text { Case } \\
\text { No. }\end{array}$ & Authors & Year & $\begin{array}{l}\text { Age } \\
\text { (yrs) }\end{array}$ & Sex & Associated Findings & Type of Hyperlipaemia & Notes \\
\hline 1 & Wagener & 1922 & 9 & $\mathrm{M}$ & $\begin{array}{l}\text { Lymphatic leukaemia } \\
\text { treated by radium }\end{array}$ & Transportation & \\
\hline 2 & \multirow[t]{2}{*}{$\begin{array}{l}\text { Holt, Aylward, } \\
\text { and Timbres }\end{array}$} & \multirow[t]{2}{*}{1939} & 11 & $\mathrm{~F}$ & $\begin{array}{l}\text { Hepato-splenomegaly } \\
\text { Abdominal pain } \\
\text { Psoriasis } \\
\text { Skin ulcers }\end{array}$ & $\begin{array}{l}\text { Idiopathic (familial) in } \\
\text { children (Bürger-Grütz) }\end{array}$ & Sib of No. 3 \\
\hline 3 & & & $2 \frac{1}{2}$ & $\mathbf{M}$ & Hepato-splenomegaly & $\begin{array}{l}\text { Idiopathic (familial) in } \\
\text { children (Bürger-Grütz) }\end{array}$ & Sib of No. 2 \\
\hline 4 & $\begin{array}{l}\text { Bernstein, Williams, } \\
\text { Hummel, Shepherd, } \\
\text { and Erickson }\end{array}$ & 1939 & 7 & $\mathbf{M}$ & Splenomegaly & $\begin{array}{l}\text { Idiopathic (familial) in } \\
\text { children (Bürger-Grütz) }\end{array}$ & \\
\hline 5 & $\begin{array}{l}\text { Goodman, Shuman, } \\
\text { and Goodman }\end{array}$ & 1940 & 1 & $\mathbf{M}$ & $\begin{array}{l}\text { Hepato-splenomegaly } \\
\text { Xanthomatosis }\end{array}$ & $\begin{array}{l}\text { Idiopathic (familial) in } \\
\text { children (Bürger-Grütz) }\end{array}$ & \\
\hline 6 & Kauffman & 1943 & 25 & $\mathbf{M}$ & Alcoholic gastritis & Transportation & \\
\hline 7 & Lepard & 1944 & 6 & $\mathbf{M}$ & Hepato-splenomegaly & $\begin{array}{c}\text { Idiopathic (familial) in } \\
\text { children (Bürger-Grütz) }\end{array}$ & \\
\hline 8 & Grossmann and $\mathrm{Hitz}$ & 1948 & 55 & $\mathbf{M}$ & $\begin{array}{l}\text { Hepatomegaly } \\
\text { Abdominal pain }\end{array}$ & Idiopathic in adults & \\
\hline \multirow{2}{*}{10} & \multirow{3}{*}{ Groom and Rucker } & \multirow{3}{*}{1950} & 59 & $\mathbf{M}$ & $\begin{array}{l}\text { Lipaemia retinalis dis- } \\
\text { covered at routine } \\
\text { clinical examination }\end{array}$ & Idiopathic in adults & \\
\hline & & & 33 & $\mathbf{M}$ & Chronic alcoholism & Transportation & \\
\hline 11 & & & 7 mths & $\mathbf{M}$ & $\begin{array}{l}\text { Niemann-Pick's } \\
\text { disease }\end{array}$ & - & $\begin{array}{l}\text { Lipid storage } \\
\text { disorder }\end{array}$ \\
\hline 12 & Dunphy & 1950 & 47 & $\mathbf{M}$ & Xanthomatosis & Idiopathic in adults & \\
\hline 13 & Everett & 1952 & $3 \frac{1}{2}$ & $\mathbf{M}$ & $\begin{array}{l}\text { Epilepsy treated with } \\
\text { high fat diet }\end{array}$ & $\begin{array}{l}\text { ?Physiological } \\
\text { ?Idiopathic (familial) in } \\
\text { children (Bürger-Grütz) }\end{array}$ & \\
\hline 14 & Davies & 1955 & 39 & $\mathbf{M}$ & $\begin{array}{l}\text { Xanthoma eruptivum } \\
\text { Splenomegaly }\end{array}$ & Idiopathic in adults & \\
\hline 15 & Cullen and Conacher & 1964 & 40 & $\mathbf{M}$ & Abdominal pain & Idiopathic in adults & \\
\hline
\end{tabular}

TABLE II

SUMMARY OF REPORTED CASES OF IDIOPATHIC LIPAEMIA RETINALIS 
there is a physiological rise in the neutral fat in the blood, which reaches its maximum in 3 to 6 hours and then gradually declines. This is termed alimentary or physiological hyperlipaemia. Two other forms of hyperlipaemia were classified by Thannhauser (1958) as follows:

(a) Transportation Hyperlipaemia.-This is due to over-abundant mobilization of fat from the storage depots and is exemplified by diabetes mellitus. Other examples are seen in chronic alcoholism where there is damage to the liver or pancreas. It can also occur in starvation, severe anaemias, the leukaemias, and lipid nephrosis. Certain poisons, such as phosphorus, which cause liver damage, can also produce this type of hyperlipaemia.

(b) Retention Hyperlipaemia, which is extremely rare, is due to defective removal of fat from the blood and to its sluggish deposition in the fat depots. In this condition other lipids, especially cholesterol and phospholipid, may also be elevated, but the greatest increase occurs in the serum neutral fat levels.

The syndrome of retention hyperlipaemia was first described by Bürger and Grütz (1932) and the designation "idiopathic" was added by Holt, Aylward, and Timbres (1939). This disease is generally seen in children, is often familial, and has the following characteristics:

(1) Hepatosplenomegaly.

(2) Abdominal cramps and occasional vomiting.

(3) Cutaneous xanthomatosis (due to associated hypercholesterolaemia).

(4) Lipaemia retinalis.

The patients are otherwise in good health and the underlying cause is entirely unknown. The case reported in this communication is an example of this type of hyperlipaemia.

Apart from lipaemia retinalis, other types of retinal involvement in idiopathic hyperlipaemia have been recorded. Thomas and Smith (1958) reported a case which exhibited macular oedema, retinal haemorrhages, and numerous small yellowishwhite retinal deposits in both eyes, which were considered to represent minute xanthomata. Blodi (1960) reported the clinical and pathological findings in a similar case in which one eye only was involved and there were large yellowish deposits in the periphery of the fundus. Retinal detachment ensued and the clinical picture was very similar to that seen in Coats's disease.

Lipid keratitis and xanthoma of the lids have also been reported in idiopathic hyperlipaemia (Dunphy, 1950).

The cases of Wagener (1922), a boy of 9 years with lymphatic leukaemia, of Kauffman (1943), a man of 25 years with alcoholic gastritis, and the second case of Groom and Rucker (1950), a man of 33 years, also with chronic alcoholism, are probably examples of transportation hyperlipaemia. Groom and Rucker's third case was a boy with Niemann-Pick disease, a lipid storage disorder due to a disturbance of intracellular lipid metabolism and thus quite different from the hyperlipaemias under discussion.

The two cases of Holt and others (1939), an 11-year-old girl who presented with hepatosplenomegaly, abdominal pains, psoriasis, and skin ulceration, and her 
brother aged $2 \frac{1}{2}$, who had an enlarged spleen and liver, were the first cases of true idiopathic familial hyperlipaemia to be reported with lipaemia retinalis. The case reported by Bernstein, Williams, Hummel, Shepherd, and Erickson (1939), a 7-yearold boy with splenomegaly, and that of Goodman, Shuman, and Goodman (1940), a 1-year-old boy with hepatosplenomegaly and xanthomatosis, and of Lepard (1944), a 6-year-old boy with an enlarged liver and spleen, are also examples of this same condition. This type of hyperlipaemia Thannhauser lists under the title of idiopathic (familial) hyperlipaemia in children with hepatosplenomegaly and secondary xanthoma or "hepatosplenomegale lipoidose" (type Bürger-Grütz). The case discussed by Everett (1952) may be another such example; this was in a boy aged $3 \frac{1}{2}$ who had been treated for epilepsy with a high-fat diet, so that the possibility of this being an aberrant form of physiological hyperlipaemia also arises.

Of the fourteen aforementioned cases of lipaemia retinalis, four therefore remainthose of Grossman and Hitz (1948), a man aged 55 with an enlarged liver; Groom and Rucker's first case, a man aged 59; that of Dunphy (1950), a 47-year-old man with secondary xanthomatosis; and, finally, that of Davies (1955), a 30-year-old male with xanthoma eruptivum and a palpable spleen. All these are examples of idiopathic hyperlipaemia in adults, or what Thannhauser (1958) calls "idiopathic hyperlipaemia in adults, with and without secondary eruptive xanthoma, occasionally accompanied by glycosuria and hepatosplenomegaly", or what could also be called adult Bürger-Grütz disease. Our case undoubtedly belongs to this group and it is interesting that, including our patient, all the five reported cases were males whose ages ranged from 30 to 59 years. This condition responds to treatment with a lowfat diet, as does the juvenile form, and the prognosis, as far as is known, is good.

The treatment given to our patient is of interest; because he had failed, in the past, to adhere to a low-fat diet, he was given a new blood lipid reducing agent C.P.I.B. (Atromid-S), which has been shown by Oliver $(1962 ; 1963)$ to produce a significant reduction in blood lipid levels in patients with ischaemic heart disease. It has also been shown by Ireland, Cullen, Oliver, and Duncan (1963), and Cullen (1963) to be effective in clearing retinal exudates in patients with exudative diabetic retinopathy, with concomitant reduction in blood lipid levels. The response to treatment in this case of idiopathic hyperlipaemia was somewhat irregular. A considerable reduction in the serum cholesterol and unesterified fatty acids was obtained, but the triglycerides fell initially only to rise again at the most recent estimation. There was, however, a concomitant regression in the retinal lipaemia, but naked eye hyperlipaemia has persisted at all times, even in blood obtained in the fasting state.

\section{Summary}

The authors report the fifteenth case of lipaemia retinalis occurring in a nondiabetic and non-xanthomatous subject. The previously reported cases of this condition are analysed and the type of hyperlipaemia with which they were associated is designated. The patient reported belongs to the group of idiopathic hyperlipaemia associated with lipaemia retinalis occurring in adults, of which this is the fifth recorded example. A note is made of a new therapeutic agent used in this condition.

We wish to thank Dr. M. F. Oliver for carrying out the blood lipid investigations in our patients and for his helpful advice in the preparation of this paper. 


\section{REFERENCES}

Appelmans, M., Michiels, J., de Vloo, N., Jamotton, L., and Massa, J.-M. (1961). Arch. Ophtal. (Paris), 21, 5.

Bernstein, S. S., Williams, H. H., Hummel, F. C., Shepherd, M. L., and Erickson, B. N. (1939). J. Pediat., 14, 570.

BLodi, F. C. (1960). Trans. Amer. Acad. Ophthal. Otolaryng., 64, 720.

Bürger, M., and Grürz, O. (1932). Arch. Derm. Syph. (Berl.), 166, 542.

CuLlen, J. F. (1963). Unpublished data presented at meeting of Association for Eye Research, London, in November, 1963.

Davies, W. S. (1955). A.M.A. Arch. Ophthal., 53, 105.

DUKE-ELDER, S. (1940). "Text-book of Ophthalmology", vol. 3, p. 2743. Kimpton, London.

DunPHY, E. B. (1950). Amer. J. Ophthal., 33, 1579.

EVERETT, W. G. (1952). A.M.A. Arch. Ophthal., 48, 712.

GodDe-Jolly, D., and Bonnin, P. (1961). Ann. Oculist. (Paris), 194, 673.

Goodman, M., Shuman, H., and Goodman, S. (1940). J. Pediat., 16, 596.

Groom, J. J., and RUCKER, C. W. (1950). Amer. J. Ophthal., 33, 1238.

Grossmann, E. E., and Hitz, J. B. (1948). Arch. Ophthal. (Chicago), 40, 570.

Holt, L. E., Aylward, F. X., and Timbres, H. G. (1939). Bull. Johns Hopk. Hosp., 64, 279.

Ireland, J. T., Cullen, J. F., Oliver, M. F., and Duncan, L. J. P. (1963). J. Atheroscler. Res., 3, 701.

Kauffman, M. L. (1943). Amer. J. Ophthal., 26, 1205.

Laws, H. W., and Harpur, E. R. (1958). A.M.A. Arch. Ophthal., 59, 521.

LEPARD, C. W. (1944). Arch. Ophthal. (Chicago), 32, 37.

OlIVER, M. F. (1962). Lancet, 1, 1321. (1963). J. Atheroscler. Res., 3, 427.

Parker, W. R., and Culler, A. M. (1930). Amer. J. Ophthal., 13, 573.

Thannhauser, S. J. (1958). "Lipidoses", 3rd ed., pp. 264-296. Grune and Stratton, New York.

Thomas, P. K., and SмIтн, E. B. (1958). Brit. J. Ophthal., 42, 501.

WAGENER, H. P. (1922). Amer. J. Ophthal., 5, 521. 